\title{
Could the Recession have Been Shortened in Romania after the 2009 Crisis? A Short Answer Given by Fiscal Multipliers during Recessions
}

\author{
Radu Soviani $^{1}$ \\ ${ }^{1}$ The Academy of Economic Studies from Bucharest, Bucharest, Romania \\ Correspondence: Radu Soviani, The Academy of Economic Studies from Bucharest, Bucharest, Romania.. \\ E-mail: radu@ soviani.com
}

Received: August 9, 2015

Accepted: September 28, $2015 \quad$ Online Published: October 25, 2015

doi:10.5539/ijef.v7n11p170

URL: http://dx.doi.org/10.5539/ijef.v7n11p170

\begin{abstract}
The experience of the large fiscal adjustments shows their efficiency depends mainly on how much is to be adjusted, the factors that contributed to the fiscal disequilibrium and their structure (discretionary or imposed by the economic environment), the size and the quality of the adjustment measures and the pace of reaction of the fiscal authorities. In this paper we analyze the size of the fiscal adjustment of the Romanian economy during the recession of 2009-2012 relatively to previous large fiscal adjustments in the European Union before the Great Recession. We determine if the measures that were taken in Romania were properly sized by using a simple method for determining the fiscal multipliers for the Romanian economy, based on recent findings of the international literature. Our findings show that the fiscal adjustment made in Romania between 2009-2012 was the fastest in the European Union with the highest yearly pace (we use as reference the adjustments prior to the Great Recession) and that the Romanian recession could have been shortened by at least one year. Our findings provide an argument that the austerity measures might cure an economy but if their size is improper, it might lower their long term potential.
\end{abstract}

Keywords: fiscal adjustment, austerity, Romanian financial crisis, fiscal multipliers, fiscal policy

\section{Introduction}

The Romanian financial crisis of 2009 followed an exceptionally period of 9 years continuously economic growth (2000-2008), when the average real GDP growth was 6.06\% of GDP. This growth was fueled by three main factors: Romania's NATO membership (2003), Romania's European Union (EU) membership (2007), the easy credit conditions on the global financial markets prior to the Great Recession. The first half of the expansion period (2000-2004) was characterized by sustainable economic growth reflected in the macroeconomic indicators (high growth, disinflation, lowering public debt, lowering fiscal deficit and a more stable labor market influenced by the privatization and liberalization of the workforce in the context of the EU convergence process). The second part of the expansion period was characterized by on overheating of the economy while higher economic growth (7\% yearly average between 2005-2008) was fueling external vulnerabilities (the current account deficit increased from $-4.8 \%$ of GDP in 2004 to $-11.2 \%$ of GDP in 2008). The vulnerabilities were also amplified by a 50\% per year internal credit growth between 2005-2008, while most of the credit was given in foreign currency (in 2008, before the start of the financial crisis, the share of credit in foreign reserves was $56 \%$ of the total loans). Moreover, the fiscal policy proved to be pro-cyclical by tax cuts that amplified the fiscal deficit from $-1.2 \%$ of GDP in 2004 to $-5.6 \%$ of GDP in 2008. With this major disequilibrium, when the financial crisis hit Romania in September 2008, the economy turned sharply lower ( $-7.1 \%$ in 2009 comparing with $+8.6 \%$ in 2008), with major economic activity decrease and even higher negative fiscal balances. For dealing with the crisis, Romania initiated 3 IMF programs between 2009 and 2015. As a result, Romania applied harsh austerity measures (increased the VAT by 5 percentage points in 2010, from 19\% to $24 \%$ while cutting public wages by 25 percent in the same time). The so-called austerity package helped reinstall the macroeconomic environment, but also pushed back the Romanian economy in the recession. After a fluctuation of the quarterly economic growth in 2011-2012, Romania finally turned the stance of the economy by eliminating volatility in growth from 2012. We want to clarify in this paper if the austerity package that aimed fiscal consolidation was properly sized or it had as an effect a prolonged recession. 


\section{Conceptual and Theoretical Concept}

We took into consideration three streams of literature that are relevant for the size and the pace of the fiscal adjustment. First, the fiscal rules that had to be followed during normal times of growth for the economic activity, despite the election cycle. Second we looked at the literature that comprises the elasticity for the different taxes and public expenditures on the public budget. Third, the size of the fiscal multipliers is associated with the structure of the economy.

The fiscal rules usually are not the same on a long period and they are imposed by different political views depending on the election cycle. Alesina, Ardagna, Perotti, and Schiantarelli (2002) find out a sizable negative effect of public spending, and in particular its public wage component on business investment, so the government conditions of employment increase wage pressures during an economic boom on the private sector wages. Alesina and Perotti (1995) argue that on average, fiscal expenses are the results of increases in expenditures, while contractions are typically caused by tax increases. The same study shows that even major successful fiscal adjustments do not seem to have recessionary consequences, on average, different types of governments show different results at implementing successful fiscal adjustments, with coalition governments showing the worst performances. We will argue that in the case of Romania, the fiscal adjustment was successful but the recession was prolonged both in size and duration. Kopits and Symanski (1998) define the fiscal rules as a permanent constrain on the fiscal policy that is expressed by some synthetic performance indicators such as the public budget balance, current public lending and public debt. Kopits (2001) shows that all fiscal rules have something in common: they try to consolidate the credibility of the macroeconomic policies by cutting the fiscal discretionary measures amplitude. Their goal is to grant that economic fundamentals are going to stay robust and predictable, no matter what government rules the economy. Most of all, fiscal rules are perceived as efficient just after a successful period when they were applied, so they drew a historical positive track-record.

Recent economic literature on the elasticity of the taxes and public expenses studies the business cycle influences on the public budget balance. For instance, Mourre, Astarita, and Princen (2014) show the EU methodology for calculating the cyclical deficit and they obtain budgetary semi-elasticity values after the OECD recent revision of the elasticity for the revenues and expenditures. The same authors calculated the effect of these elasticity indicators on the cyclical deficit. As the determining of the cyclical stance of the economy is the key element for obtaining the cyclical deficit, the authors quoted calculate the parameters for the cyclical adjustment (budgetary semi-elasticity). We used Mourre, Astarita, and Princen (2014) findings for Romania (income elasticity) in determining the size of the adjustment on the Romanian economy during 2010.

The vast majority of the economic literature dedicated to fiscal multipliers shows that it is not easy to calculate the net fiscal multiplier. Barro (2013) argues that it is difficult to estimate government spending multiplier because of reverse-causation spending reacting to economy. One argument that Barro (2013) takes into consideration is government tends to be pro-cyclical in purchases-up in booms, down in recessions-and, if this is not taken into account, we might get overestimates of the fiscal multiplier. Auerbach and Gorodnichenko (2010) found out that the size of the multiplier it's different over the business cycle). Their study used regime-switching models, and found large differences in the size of spending multipliers in recessions and expansions, with fiscal policy being considerable more effective in recessions than in expansions. This is against Blanchard and Perotti (2002) findings that fiscal multipliers do not vary over the business cycle. Spilimbergo, Symansky, and Schindler (2009) argue the size of the fiscal multiplier depends on the country, time, and circumstances, while temporary or permanent changes in fiscal policy produce larger multipliers depending on the fiscal measure. The same study concludes that the four broad methodologies to calculate fiscal multipliers (model simulations, case studies, vector auto-regressions, econometric studies of consumer behavior in response to financial shocks) have shortcomings and caveats because any estimate of the multiplier should have in mind the assumption under which is valid.

Therefore, for estimating the fiscal multiplier for Romania, we selected the recent findings of Batini, Eyraud \& Weber (2014) that propose a simple method ("bucket approach") to come up with reasonable multiplier estimates. The approach groups countries with similar multiplier values, based on their characteristics. It also takes into account the effects of some temporary factors, such as the state of the business cycle. The characteristics Batini, Eyraud, and Weber (2014) use for grouping emerging economies take into consideration their tendency to have higher or lower fiscal multipliers dependent on some particularities. The factors that contribute to higher fiscal multipliers look at the degree of trade openness (the economies that are importing less have higher multipliers), labor force rigidity (higher multiplier), the size of the automatic stabilizers (high automatic stabilizers decrease the fiscal multiplier since some of the incomes are coming back to the public budget), foreign exchange rate regime (fiscal multipliers are lower in a managed float exchange regime since the 
exchange rate might compensate the impact of the discretionary fiscal policy measures), the level of public debt (high indebted countries have lower multipliers if a successful fiscal consolidation leads to a decrease of the borrowing rates), and the quality of the management for the public expenditures and for the public revenues. According to those factors, Batini, Eyraud, and Weber (2014) set a binary score (1 or 0,1 for respecting the criteria and zero for not respecting the structural criteria) and calculates by summing the values of the fiscal multipliers for the first year. Taking into consideration other researches on fiscal multipliers, the same study sets a range for the fiscal multipliers as follows:

- Low multiplier economies: 0.1-0.3;

- Medium multiplier economies: 0.4-0.6;

- Higher multiplier economies: 0.7-1.

The methodology continues by adjusting the range according to the business cycle (by up to $40 \%$ if the economy is at peak and by up to $60 \%$ if the economy is on the highest point of the recession, so the output gap is maximal). Then it adjusts the monetary policy stance (by $30 \%$ if the monetary policy is close to zero bound interest rate and by $0-30 \%$ if the monetary policy has other constraints. The final value of the multiplier is given by formula:

$$
M=M n t *(1+\text { cycle }) *(1+\text { Mon })
$$

Where Mnt is the fiscal multiplier in normal times, cycle is the score after the business cycle adjustment (and is between $-0.4+0.6$ ) and Mon is the monetary policy stance (between $0-0.3$ ).

In the next 2 sections we present the large fiscal adjustment of Romania during the financial crisis and we present our estimate on the fiscal multiplier as suggested by the literature that was just discussed, or more specific by the simple method defined by Batini, Eyraud, and Weber (2014).

\section{How Large Was the Fiscal Adjustment in Romania}

In this section we will make a short overview for the fiscal policy of Romania in terms of the expansion phase of the business cycle that started in 2000. We analyze two macroeconomic indicators (economic growth, budgetary balance) and their dynamics after 2004. The year 2004 is especially important because after an election cycle, the new Government switched the fiscal policy in terms of discretionary measures. Starting January $1^{\text {st }} 2005$, Romania abandoned the progressive income taxation, with tax brackets from $18 \%$ (low wages) to $40 \%$ (high wages) and a medium bracket of $23 \%$. Instead, the fiscal policy adopted a flat tax income regime (16\%) and simultaneously cut the companies profit taxation with 9 percentage points (from $25 \%$ to $16 \%$ ). As a result, the economic growth was fueled above potential, and the budgetary balances started to deteriorate. Figure 1 shows the Romanian economic growth between 2000-2008 and the budget balance in the same period. As data prove, the budget deficit grew from $-1.2 \%$ of GDP in 2005 to $-5.6 \%$ of GDP in 2008, while the average economic growth during this period had an average of $6.9 \%$. The fiscal policy proved to be pro-cyclical (while the economy was growing fast, the fiscal policy provided additional stimulus).

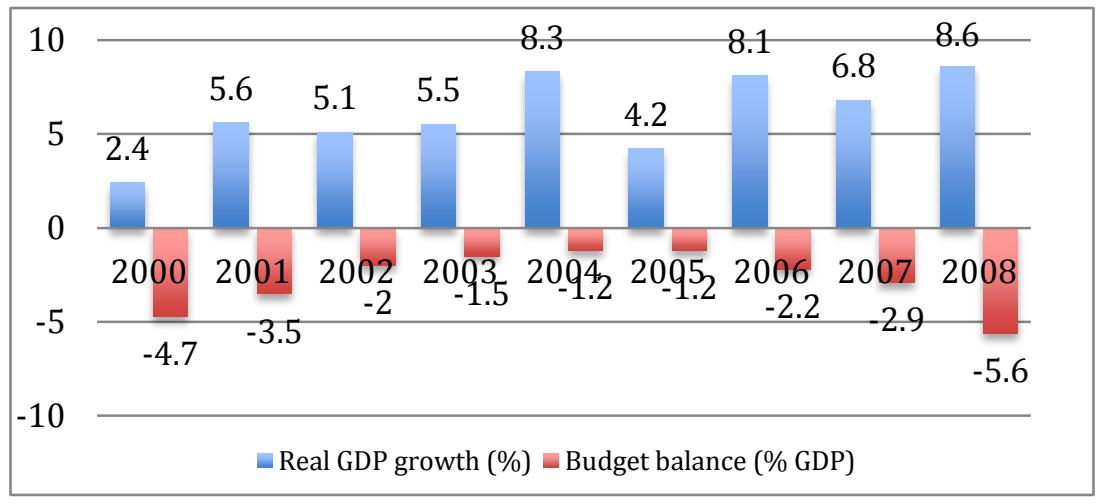

Figure 1. Romania's GDP and budget deficit dynamics, 2000-2008

Source: EU Ameco Database.

While the crisis unfolded, Romania faced a balance of payments crisis because the lack of financing of the current account deficit (that grew between 2004-2008 from -4.8\% of GDP to -11.2\% of GDP in 2008). The credit 
crunch that followed the Great Recession put pressure on the financing so the economic activity switched from boom to bust, decreasing the budgetary revenues, while the fiscal policy hesitated to cut the expenses. The effect was the widening of the budgetary deficit to $-8.9 \%$ of GDP in 2009.

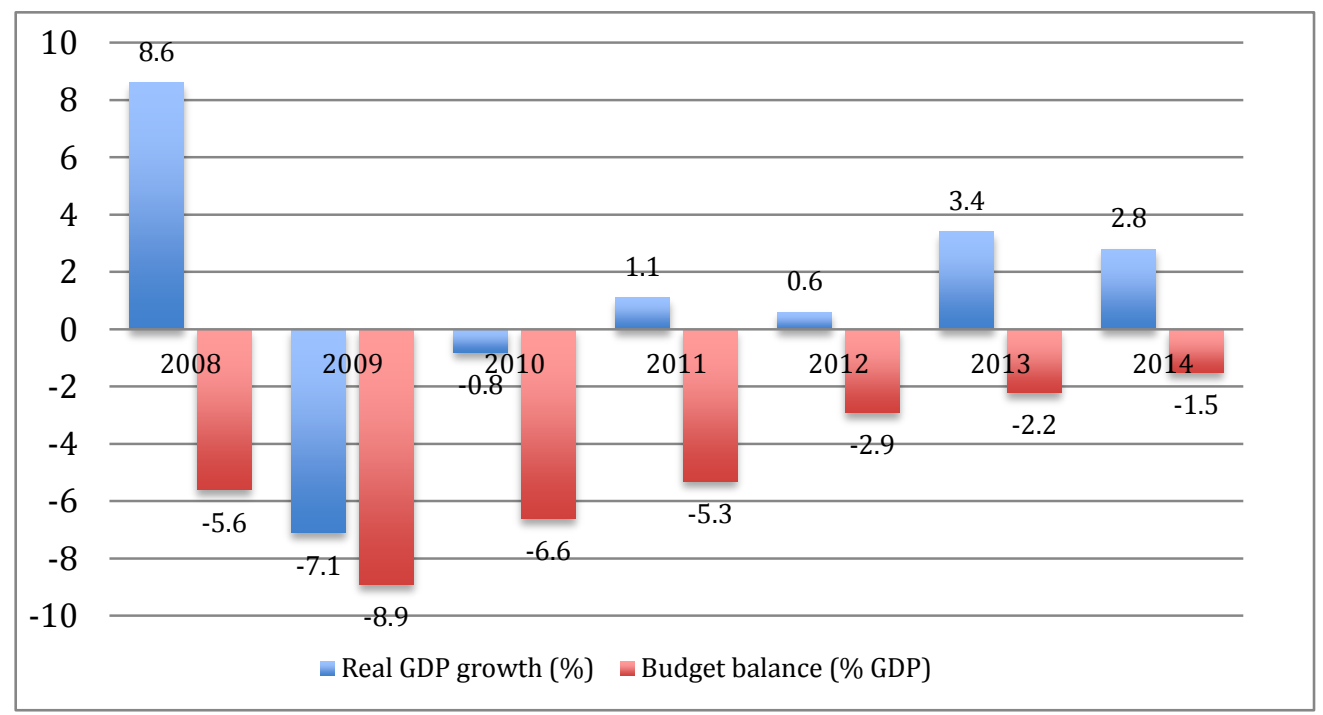

Figure 2. Romania's GDP growth and budget balance (2008-2014)

Source: EU AMECO Database.

Facing a balance of payment crisis, and with a short term debt representing $83 \%$ of the official foreign exchange reserve, the Romanian Government turned to the IMF for help and started implementing a set of measures for addressing the Romanian public finances. The measures were concentrated mainly on cutting expenses and, in May 2010, Romania decided a VAT increase from $19 \%$ to $24 \%$, while cutting the public wages by $25 \%$. This rescue package is the most severe answer in terms of austerity that was implemented in a country from the European Union during the Great Recession (both in terms of size, and simultaneity).

The fiscal measures were implemented in an ad-hoc manner (with less than a month prior-notice to the economy). The goal of the rescue package was to adjust the budget balance to less than $-3 \%$ and to set the fiscal policy in order to adjust the structural budget deficit to less than $-3 \%$ as well. The structural deficit is the budget balance after extracting the cyclical component from the accrual deficit, while the cyclical deficit is the budget balance related to the business cycle. Figure 3 shows the adjustment both in terms of accrual deficit and structural deficit in the Romanian economy during the financial crisis.

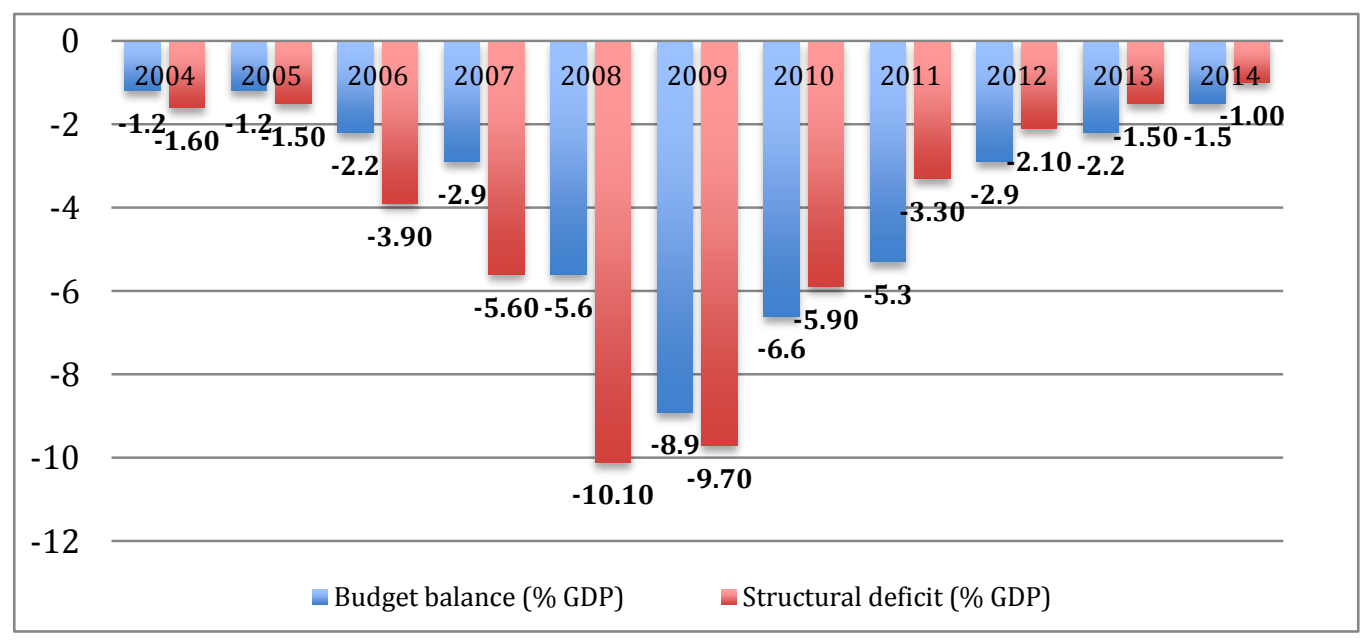

Figure 3. Romania's fiscal adjustment in terms of structural and budgetary deficit 
Socol and Soviani (2010) analyze the large fiscal adjustment made in 12 European Union members (or on their way to become members) in the last 30+ years before the Great Recession. Since in 2010 the fiscal adjustment of Romania was just on its way to become large and we didn't have the final size and duration of the adjustment, in this paper we are able to set the final results of the fiscal adjustment for Romania, both in terms of duration and average annual adjustment for the structural deficit. The results are shown in Table 1:

Table 1. The experience of the large fiscal adjustments in EU countries before the great recession and Romania's performance in the financial crisis

\begin{tabular}{lccc}
\hline Country & Fiscal adjustment time frame & No. of years & $\begin{array}{c}\text { Annual average of the structural deficit } \\
\text { adjustment (\% of GDP) }\end{array}$ \\
\hline Romania & $2009-2012$ & 3 & 2,53 \\
Denmark & $1982-1986$ & 4 & 2.5 \\
Greece & $1989-1994$ & 5 & 2.2 \\
Sweden & $1993-1998$ & 5 & 1.8 \\
Ireland & $1985-1989$ & 4 & 1.5 \\
Portugal & $1986-1989$ & 6 & 1.4 \\
Italy & $1989-1997$ & 8 & 1.3 \\
UK & $1993-1999$ & 6 & 1.2 \\
Finland & $1992-2000$ & 8 & 1 \\
France & $1993-1997$ & 4 & 0.9 \\
Belgium & $1981-1990$ & 9 & 0.9 \\
Austria & $1995-2001$ & 6 & 0.8 \\
Netherlands & $1990-2000$ & 10 & 0.4 \\
\hline
\end{tabular}

Source: Socol and Soviani (2010),p.25, this paper results.

As we can see, the Romanian fiscal adjustment lasted 3 years and had a pace of $2.53 \%$ of GDP in terms of the average annual adjustment of the structural deficit, so Romania has the highest annual adjustment and the fastest ( 3 years) in terms of duration. The average duration of the fiscal adjustments before the Great Recession for the EU countries was 6 years ( $+50 \%$ comparing to Romania) while the yearly average adjustment was $75 \%$ of Romania's size of the adjustment (1.9\%). The results clearly show that the large fiscal adjustment of Romania in the financial crisis was very fast and very strong. With those results, we will try to determine in the next section if the fiscal measures could have been less ample and we estimate the results in terms of the length of the recession.

\section{A Simple Method Based on the Fiscal Multipliers for Determining if Romania's Economy Recession Could have Been Shortened}

In this subsection we will determine the size of fiscal multipliers for Romania in 2010, according to Batini, Eyraud and Weber (2014) methodology, as described earlier. Then, we will use the elasticity factor determined by Mourre, Astarita, and Princen (2014) for Romania, according to the EU methodology, and we'll determine the costs of the fiscal measures applied in Romania (2010) in terms of economic growth.

Phase 1: Calculating the score for Romania based on structural characteristics. The score for Romania in 2010 is summarized in Table 2, and we used the following rules for calculating each score:

Regarding the openness of trade we assigned "1" value to this characteristic, having in mind that in the last 5 year before 2010, more than $30 \%$ of the consumption was based on imports. The import dynamics also contributed to deteriorate the current account deficit, from $-4.8 \%$ of GDP in 2004 to $-11.2 \%$ of GDP in 2008 with a maximum of $-13.4 \%$ in 2007.

Regarding the rigidity of the labor force, we assigned "1" value to this characteristic. We had in mind that by the time of 2010, the labor market was characterized by minimum wage, constraints in firing employees and strong unions. So the Romanian labor force market was not flexible in 2010. After 2011, the flexibility gained steam by a change in the legislation (National Labor Code), but in 2010 the labor market was definitely rigid.

Regarding the size of the automatic stabilizers, Batini, Eyraud \& Weber (2014) methodology sets as a criterion that the stabilizers are small if the public expenditure is under 40\% of GDP. The average in 2005-2009 was 37.3\% of GDP. So we assigned the " 1 " value to the size of the automatic stabilizers criteria. 
Regarding the fixed exchange rate criteria, we assigned " 0 " to the score, having in mind the targeting inflation regime applied in Romania used a managed float exchange rate policy and in the pre-crisis period there was a significant volatility of the foreign exchange rate.

Regarding the public debt criteria, we assigned "1" to the score, having in mind that in 2010 , the public debt was $37.5 \%$ of GDP, or almost half of the Maastricht Treaty Criteria (60\% of GDP).

Regarding the efficiency of the public revenues management we assigned " 0 ", having in mind the public revenues never exceeded $35.4 \%$ of GDP (and this happened in 2007 when the economy was overheated) and the economic boom had as a result widening deficits instead of lowering them.

Table 2. The score for Romania based on structural characteristics in 2010

\begin{tabular}{lc}
\hline Structural characteristics & Score \\
\hline Trade openness ( $>30 \%$ of consumption from imports) & 1 \\
Rigidity of the labor market & 1 \\
Low automatic stabilizers (expenditure \% of GDP<40\%) & 1 \\
Fixed exchange rate & 0 \\
Low public debt & 1 \\
The efficiency of the public debt management & 0 \\
TOTAL & 4 \\
\hline
\end{tabular}

Source: own calculations according to the criteria mentioned above.

As Batini, Eyraud, and Weber (2014) demonstrate, the economies with a score of 3-4 have a medium fiscal multiplier (in the range 0.4-0.6), we will use the range 0.4-0.6 for Romania.

Phase 2: Adjusting the output gap according to the business cycle and the monetary policy stance.

- Adjusting to the business cycle: in 2010, the output gap in Romania was -2.2\% (AMECO database) compared with $-8.6 \%$ in 2009. We considered an adjustment factor of 0.3 (for the 2009 situation, when the output gap was maximal, we would have assigned 0.6 as adjustment factor). Our adjustment shows a moderate factor of adjustment when the output gap is negative, but not very large.

- $\quad$ Adjusting to the monetary policy: in 2010, the monetary policy interest rate in Romania was high (above $7 \%$ ), so there was space for further adjustment. But Romania had a majority stance of the banking loans denominated in foreign exchange, and, by the end of 2010, the size of non-performing loans (NPL) went from $2.8 \%$ in 2008 to $11.8 \%$ in 2010 (mostly because of the exchange rate devaluation that put pressure on the debtors capacity to return loans). By 2013, the NPL share in total credit was $22 \%$. Since the methodology used considers a range of monetary policy adjustment of $(0-0.3), 0.3$ being the no maneuver value for the monetary policy, we consider a median adjustment factor of 0.15 . We took into consideration that the monetary policy can still adjust, but the size and the pace of the adjustment is limited by the risks derived from the structure of the bank loans.

Phase 3: Calculating the final range for the fiscal multiplier in Romania, 2010.

- $\quad$ The lower range $(\mathrm{Ml})=0.4 * 1.3 * 1.15=0.598$

- The upper range $(\mathrm{Mu})=0.6 * 1.3 * 1.15=0.897$

Thus, we estimated the range for the fiscal multiplier in case of Romania, 2010, as (0.6-0.9).

Phase 4: Setting the frame for different public revenues elasticity.

We used the findings of Mourre, Astarita, and Princen (2014) for the elasticity in case of Romania. He finds 1.29 elasticity for the income tax (as cutting nominal wages in the public sector) and the 1 elasticity for the indirect taxes (as VAT).

Phase 5: We extract from the Romanian Public Budget Execution (2010) the effects on the VAT revenues and income tax revenues in 2010, to determine the influence of the VAT five percentage point increase (from 19\% to $24 \%$ in May 2010) and the influence of the 25 percentage points cut in the public wages sector (effective in June 2010). Leu/Lei is the national currency of Romania.

In 2010, the total VAT revenues were 39.24 billion lei, and before the VAT rate increase, the revenues were 16.43 billion lei. We extrapolate the results and find that the VAT hike extracted from the economy 6.38 billion lei in 
2010. Using the fiscal multiplier determined above, we find a negative effect on the economic activity in the range of 3.83 billion lei-5.74 billion lei.

In 2010, the total expenses with the public employees stood at 42.8 billion lei, comparing to 46.8 billion lei in 2009. So, the public wages cut extracted from the economy 4.6 billion lei. Using the income tax elasticity (1.29) and the fiscal multipliers as determined above, we find that the fiscal policy extracted from the economy, 2.76-4.14 billion lei, by cutting public wages, in addition to the VAT measures.

By adding the two elements, we conclude the fiscal policy extracted from the economy between 6.59-9.88 billion lei, in real terms. We take into consideration that in 2010, Romania's real GDP was 533.9 billion lei (-4.3 billion lei under the 2009 GDP) and as a result the real GDP contraction was $-0.8 \%$.

As a conclusion, we find that without implementing the two austerity measures, we are able to estimate that real GDP growth in 2010 would have been positive and between $1.23 \%-1.85 \%$, so the economy would have exit the recession in 2010 instead of 2011. We might take into consideration that fiscal multipliers have longer effects (up to 4 years), so the pro-cyclical fiscal policy adjustment extracted from the economy even more than we showed.

Two more elements are important for this paper: the public wage cut of 2010 was reversed in two consecutive moments $(2011,2012)$ and this also shows that the initial size of the cut was too large. The second element is related to the pace of the fiscal adjustment. As previously shown in subsection 3, the average duration of the fiscal adjustments before the Great Recession for the EU countries was 6 years $(+50 \%$ comparing to Romania) while the yearly average adjustment was $68 \%$ of Romania's size of the adjustment (1.9\%). So the fiscal adjustment of Romania made by austerity measures was shorter and larger than the previous ones.

\section{Conclusions}

Generally, we found that imposing austerity measures will finally fix the public finances of an economy and it did so in the case of Romania. We also found that the size of the austerity measures in Romania was fueling another year of economic activity contraction, in other words, an extra year of recession. This is shown by our estimation (how the economy would have performed without the fiscal austerity measures). As a result of the austerity, Romania had the highest large fiscal adjustment (comparing to other EU economies before the Great Recession) in terms of adjusting the structural deficit (1.9\% per year), and the shortest one in terms of duration: 3 years. While succeeding in adjusting the fiscal deficit, a longer period for the adjustment and an easier pace would have been more suitable for the Romanian economy and it would have been possible taken into consideration two factors: the low public debt and the low interest rate for servicing the public debt that were decreased as a result of the IMF financial support. The austerity measures were oversized (taking into consideration that the public wages cut was reversed after the initial shock, while the VAT rate stood the same until the end of 2014). A mix of the two measures would have been preferable and a lower increase of the VAT rate. The austerity was a success in terms of adjusting fiscal balance, but the pace of the adjustment made Romania face another consequence: while obtaining the full adjustment sooner than European Union rules permit, the room for further stimulating the economy by fiscal policy to close the output gap is insufficient since Romania once obtained the adjustment of the structural deficit, cannot increase it without breaking the new rules set in the European Union economies, so it lowered its potential growth. The EU rules (designated for the Eurozone economies and other countries, like Romania, that adhered to them) were imposed through the Stability and Growth Pact (SGP) and Medium Term Budgetary Objectives (MTO). Briefly, a set of rules designed to ensure that countries in the European Union pursue sound public finances and coordinate the fiscal policies.

\section{References}

Alesina, A., \& Perotti, R. (1995). Fiscal Expansions and Fiscal Adjustments in OECD Countries. NBER Working Paper No. 5214, Issued in August 1995. http://dx.doi.org/10.2307/1344590

Alesina, A., Ardagna, S., Perotti, R., \& Schiantarelli, F. (2002). Fiscal Policy, Profits and Investment. American Economic Review, 92(3), 571-589. http://dx.doi.org/10.1257/00028280260136255

Auerbach, A., \& Gordnichenko, Y. (2010). Measuring the output responses to fiscal policy. NBER Working Paper 16311, August 2010. http://dx.doi.org/10.2139/ssrn.1667585

Barro, R. (2013). Fiscal Multipliers. IMF Seminar on fiscal policies, April 2013.

Batini, N., Eyraud, L., \& Weber, A. (2014). A simple method to compute fiscal multipliers. IMF Working Paper WP/14/93, June 2014, IMF. http://dx.doi.org/10.5089/9781498357999.001

Blanchard, O., \& Perotti, R. (2002). An Empirical Characterization of the Dynamic Effects of Changes in 
Government Spending and Taxes on Output. Quarterly Journal of Economics, 117, 1329-1368. http://dx.doi.org/10.1162/003355302320935043

European Union. (n. d.). AMECO Database, Annual Macroeconomic Database. Retrieved from http://ec.europa.eu/economy_finance/db_indicators/ameco/index_en.htm

European Union. (n. d.). Medium Term Budgetary Objectives (MTO). Retrieved from http://ec.europa.eu/economy_finance/economic_governance/sgp/preventive_arm/index_en.htm

European Union. (n. d.). Stability and Growth Pact (SGP). Retrieved from http://ec.europa.eu/economy_finance/economic_governance/sgp/index_en.htm

Kopits, G. (2001). Fiscal Rules: Useful Policy Framework or Unnecessary Ornament. IMF Working Paper 1, WP01/145, September 2001, p. 105.

Kopits, G., \& Symansky, S. (1998). Fiscal policy rules. IMF occasional Paper 162, 1998, Washington DC, p. 6. http://dx.doi.org/10.5089/9781557757043.084

Mourre, G., Astarita, C., \& Princen, S. (2014). Adjusting the budget balance for the business cycle-the EU Methodology. Economic Papers 536, November 2014.

Romanian Ministry of Public Finances Database. (n. d.). Retrieved from http://www.mfinante.ro/execbug.html?pagina=buletin

Socol, C., \& Soviani, R. (2010). The experiences of the large fiscal adjustments in EU, Romania's case. Theoretical and Applied Economics, 12(553), 21-28.

Spilimbergo, A., Symansky, S., \& Schindler, M. (2009). Fiscal Multipliers. IMF Staff Position Note, SPN 09/11, May 20 2009, pp. 3-5.

\section{Copyrights}

Copyright for this article is retained by the author(s), with first publication rights granted to the journal.

This is an open-access article distributed under the terms and conditions of the Creative Commons Attribution license (http://creativecommons.org/licenses/by/3.0/). 